\title{
Obrazovanje i evangelizacija
}

Marina Novina*

marina.novina@ffrz.hr https://doi.org/10.31192/np.17.1.7

UDK: 37:27-766

Pregledni članak / Review Primljeno: 30. studenog 2018. Prihvaćeno: 30. siječnja 2019.

Cilj je ovoga rada istaknuti ulogu i značenje obrazovanja kao jednog od oblika evangelizacije. Štoviše, detaljnijim uvidom u proces obrazovanja, odnos obrazovanja $i$ kulture, te mjesta obrazovanja u društveno-političkom kontekstu ovo istraživanje dovodi do zaključka da su obrazovanje i evangelizacija dva moćna $i$ neodvojiva procesa oblikovanja identiteta osobe jer svaka informacija ujedno je $i$ formacija. Stoga možemo govoriti o nužnosti zauzetog sudjelovanja Crkve u odgojno-obrazovnim procesima i njegovu kreiranju. Briga za istinu i upoznavanje čovjeka s istinom o njegovu podrijetlu, dostojanstvu, pravima i odgovornostima, Crkvu čini odgovornom za informaciju koja ima moć transformacije, tj. oblikovanja čovjekova identiteta i lica. Briga za istinu implicira brigu za informaciju, srž je procesa evangelizacije i brige za čovjeka, njegov identitet i lice i put Crkve koji ona nikada ne smije napustiti.

Ključne riječi: obrazovanje, spoznaja, istina, informacija, evangelizacija, kultura, čovjek.

\footnotetext{
* Dr. sc. Marina Novina, asistentica, Sveučilište u Zagrebu, Fakultet filozofije i religijskih znanosti, Jordanovac 110, HR-10000 Zagreb.
} 


\section{Uvod}

Obrazovanje i evangelizacija su dva iznimno važna i moćna procesa, okrenuta budućnosti, koja u svom središtu imaju oblikovanje osobe te im stoga Crkva i društvo trebaju posvetiti osobitu pozornost. ${ }^{1}$ Štoviše, »obrazovanje je [...] doista posebni oblik evangelizacije«, istaknuo je papa Franjo. ${ }^{2}$ Počevši od apostolske pobudnice Evangelii gaudium (Radost evanđelja) iz 2013., kojom je izložio program svoga pontifikata, pa sve do danas papa Franjo je u više navrata govorio o važnosti i značenju obrazovanja u suvremenom svijetu, ali i o njegovoj važnosti za odgovor Crkve na potrebe vremena u kojem živimo. Zapravo, tom kratkom tvrdnjom papa nije samo spojio dva iznimno popularna termina već je ponovio riječi svojih brojnih prethodnika na Petrovoj stolici, ali i posvećenih muškaraca i žena, koji su tokom povijesti isticali značenje i ulogu odgojno-obrazovnog poslanja Crkve. Naime, Crkva, uvijek željna odgovoriti na konkretne potrebe čovjeka i njegova vremena, kroz povijest je ulagale velike snage u obrazovanje, $u$ intelektualnu, znanstvenu i kulturnu izgradnju čovječanstva. I u današnjem svijetu globalizacije, edukacije (znanja i znanosti) i komunikacije (informacija) ${ }^{3}$ Crkva je pozvana, istaknuo je papa Franjo, ući u dijalog $\mathrm{s}$ državama, $\mathrm{s}$ društvom po kulturi i znanostima i $\mathrm{s}$ onima koji još ne poznaju Krista. ${ }^{4} \mathrm{U}$ tom smislu obrazovanje je ono što može oblikovati čovjeka za taj dijalog (za što izvrstan primjer nalazimo u sv. Tomi Akvinskom, istaknuo je i sam papa Franjo), odnosno za susret čovjeka s budućnosti (u nadi). Stoga je obrazovanje jedna od temeljnih zadaća Crkve u suvremenom svijetu, ponovio je 9. veljače 2017. godine papa Franjo na plenarnoj skupštini Kongregacije za katolički odgoj. ${ }^{5}$ Zapravo, Crkva je svjesna da su obrazovanje i evangelizacija psihološki, sociološki, teološki i filozofijski gledano nerazdvojive teme koje, zagrebemo li ispod površine svakodnevnog diskursa, dotiču najdublja pitanja oblikovanja čovjekova identiteta, poznavanja vlastitoga podrijetla, onoga što on jest i što mu je zadaća. Obrazovanje je neizmjerno važno jer nije, kako bi mnogi željeli pokazati, samo informacija, obrazovanje je informacija i formacija.

\footnotetext{
${ }^{1}$ Rad je u skraćenom obliku izlagan na Redovničkim danima 2017. godine u Dubrovniku, Splitu, Zagrebu, Rijeci i Đakovu čija je tema bila »Odgojno-obrazovno poslanje: konstitutivna stvarnost redovničke karizme«.

2 PAPA FRANJO, Savjetovati i poučavati. Kateheza na općoj audijenciji, 23. studenog 2016., IKA - Tjedni bilten, 48 (30.11.2016), 26.

${ }^{3}$ Usp. PAPA FRANJO, Evangelii gaudium - Radost evandelja. Apostolska pobudnica o naviještanju evanđelja u današnjem svijetu (24.XI.2013), br. 52, Zagreb, Kršćanska sadašnjost, 2015, 47 (dalje EG).

${ }^{4}$ Usp. isto, 179-180.

${ }^{5}$ Usp. PAPA FRANJO, Discorso del santo padre Francesco ai partecipanti alla plenaria della congregazione per l'educazione cattolica (degli istituti di studi), w2.vatican.va/content/ francesco/it/speeches/2017/february/documents/papa-francesco_20170209_plenariaeducazione-cattolica.html (19.10.2018).
} 
Štoviše, čovjek po naravi teži za znanjem, tražitelj je istine: »Što više čovjek zna o stvarima i svijetu, to bolje spoznaje i samoga sebe u svojoj jedinstvenoj naravi te $u$ isto vrijeme to hitnijim postaje pitanje o smislu stvari i same njegove egzistencije ${ }^{6}{ }^{6}$ a odgovor na pitanja smisla težeći za istinom naći će u Istini, u vjeri. Tako postaje razvidno da je obrazovanje na više razina značajan i moćan proces, a stoga i interesna sfera raznih društvenih i ideoloških skupina. Crkva ga prepoznaje kao poseban oblik evangelizacije, kojoj je krajnji cilj preobrazba čovječanstva. ${ }^{7}$ Zašto je obrazovanje toliko važno i moćno otkriva nam uvid u odnos obrazovanja i kulture, razumijevanje obrazovanja u suvremenom svijetu u kontekstu društveno-političkog uređenja, te odgovor na pitanje što bi to obrazovanje trebalo biti i zašto se nalazi u samoj srži poslanja Crkve.

\section{Obrazovanje i kultura}

Pojednostavljeno govoreći uočavamo da, kao što Crkva nije zgrada već je tvori skupina vjernika, tako ni država ni društvo nisu neke apstraktne tvorevine već ih sačinjavaju ljudi sa znanjima, mišljenjima, ali i etičkim, moralnim i vjerskim uvjerenjima koji zajednički, na različite načine, tvore »ukupan način života ljudi«, odnosno kulturu. Državne institucije imaju zadatak čuvati, razvijati i promicati tu kulturu.

Među temeljnim definicijama kulture nalazi se ona Ralpha Lintona koji kaže: »Kultura jednog društva jest način života njegovih pripadnika; zbirka ideja i navika što ih uče, dijele i prenose iz naraštaja u naraštaj. ${ }^{8}$ Kultura, dakle, za svoj sadržaj ima način života (tradicionalne vrijednosti) koji je usko vezan uz identitet, odnosno uz način na koji pojedinac doživljava, razumije i poznaje sebe; te uz proces učenja, odnosno obrazovanja kojim se s naraštaja na naraštaj prenosi način života. Obrazovanje (formalno i neformalno) je tako nužna sastavnica svake kulture kojoj je zadaća očuvanje i oblikovanje identiteta članova društva. U tom je smislu obrazovanje svakog člana društva jedan od temeljnih društveno-političkih interesa čije se značenje otkriva u širokom rasponu od ekonomske politike do izgradnje i očuvanja kulturnog i nacionalnog identiteta. No, to ujedno znači barem dvoje. Prvo, obrazovanje je po svom cilju, sadržaju i organizaciji društveno-politički uvjetovano. ${ }^{9}$ Odnosno, obrazovanje je društvena pojava; a) društveno uvjetovan fenomen, što znači da se njime ostvaruje

\footnotetext{
${ }^{6}$ IVAN PAVAO II., Fides et ratio - Vjera i razum. Enciklika o odnosu vjere i razuma (14.IX.1998), br. 1, Zagreb, Kršćanska sadašnjost, 1999, 7 (dalje FR).

7 Usp. PAVAO VI., Evangelii nuntiandi. Apostolski nagovor o evangelizaciji u suvremenom svijetu (8.XII.1975), br. 18, Zagreb, Kršćanska sadašnjost, 2000, (dalje EN).

${ }^{8}$ Michael HARALAMBOS, Martin HOLBORN, Sociologija. Teme i perspektive, Zagreb, Golden marketing, 2002, 884.

9 Usp. Dragutin FRANKOVIĆ, Zlatko PREGRAD, Pero ŠIMLEŠA, Enciklopedijski rječnik pedagogije, Zagreb, Matica hrvatska, 1963, 576-577.
} 
društvena svrha te da je odgojno-obrazovni proces prožet "pragmatiziranom idejom«, upravo ta ideja je razlog i temelj brojnih prijepora i nesuglasica, i b) obrazovanje je funkcija društva, odnosno sredstvo za postizanje društvenih ciljeva, društvenog napretka i socijalizacije društva pa se čak i spoznajne komponente sadržaja odgoja i obrazovanja podvrgavaju »društvenoj funkciji« (i interesu društvenih skupina s tvrdnjom da je to ujedno interes pojedinca) čime se zapravo neka ideja, odnosno vrijednost postaje arbitar u ocjenjivanju društvenog interesa i interesa pojedinca. ${ }^{10}$ Sasvim je razvidno da nije ni malo nevažno o kojoj je ideji riječ i upravo su te ideje razlog i temelj brojnih prijepora i nesuglasica - obrazovanje je vrijednosno određeno. Drugo, »biti uključen u obrazovanje (kao učitelj ili kao učenik) znači sudjelovati u 'socio-političkom polju' stoga što društvo u kojem živimo oblikuje prirodu institucija koje ga provode ${ }^{11}$ Stoga je važno razumjeti i što bolje ispuniti vlastitu ulogu ostvarenja i razvoja odgojno-obrazovnog procesa, a na to je pozvan svaki njegov sudionik, tj. svaki član društva. Obrazovanje time biva moćan »alat« u rukama države, ali i u rukama svakoga pojedinca, jer je od presudne važnosti koja će ideja biti pragmatizirana i na koji način.

U tom smislu, filozofijski gledano, razmatranje odnosa obrazovanja i kulture otvara niz iznimno važnih pitanja za suvremene rasprave oko sekularnosti koje slušamo posljednjih godina. Naime, mogu li se Crkva i država odvojiti tako da to budu dvije autonomne stvarnosti? Složeno je to pitanje na koje bi se moglo odgovoriti ovako: naravno da mogu, ali uz neke uvjete. Crkva i država se mogu odvojiti: ako se mogu odvojiti država i društvo; ako državna politika i institucije napuste svoju zadaću odražavanja, promicanja i razvitka nacionalnog identiteta i kulture - Crkva je dio društva i kulture; ako se čovjek kao nositelj identiteta i kulture, to biće koje je nužno vrijednosno obojano, može učiniti vrijednosno neutralnim - to je pak nemoguće. Mogu li, dakle, javni prostor, zajednica, društvo i država postati vrijednosno neutralni? Odgovor je logičan i jasan: ne. Filozofijski i psihološki gledano, to bi značilo rastrgati biće, učiniti ga kontradiktornim u sebi samom. Naime, vjera, odnosno uvjerenja i vrijednosti, su izvorišta i korektivi djelovanja i življenja, a ne cipele za jednu sezonu ili neki ukras u vlastitu domu, ustvrdio je u jednom od svojih nagovora i papa Franjo. ${ }^{12}$ Posljedično, kultura i društveno političko uređenje bi morali odražavati svoj sadržaj, barem u demokratskim društvima. Uz dužnu napomenu, poznavanje, poštivanje i izgradnja vlastitog identiteta ne znači isključivost za sve drugo i drugačije.

\footnotetext{
${ }^{10}$ Usp. Ilija LAVRNJA, Pedagogija između ideologije i znanosti, u: Hrvoje VRGOČ (ur.), Pedagogija i hrvatsko školstvo. Zbornik radova Sabora hrvatskih pedagoga, Zagreb, Hrvatski pedagoško-književni zbor, 1996, 86-91, 89-90.

${ }^{11}$ Maja ŽITINSKI, Education is a Moral Concept, Informatologia, 39 (2006) 3, 137-141, 137.

${ }^{12}$ Usp. PAPA FRANJO, Nagovor uz molitvu Andeo Gospodnji (18.08.2013), https://w2.vatican.

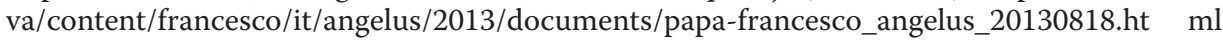
(04.09.2017).
} 
Kultura i sastavnice društveno-političkoga uređenja satkane su od ponašanja i djelovanja koja proizlaze iz znanja, vještina, stavova, mišljenja i vrijednosti pojedinaca koji tvore tzv. »kulturnu stvarnost«, odnosno društveno-politički kontekst. Taj se kontekst zrcali u identitetu svakog člana društva, ali uvijek i nužno počiva na vrijednosti koju možemo shvatiti i kao ideju, prema grč. slika, uzor, misao, nešto što je trajno i nije podložno mijenjanju, a koja bi trebala predstavljati spoznajno-ontološki sadržaj. ${ }^{13} \mathrm{Za}$ Crkvu ta trajnost i samo srce čovjekova identiteta jest njegovo božansko podrijetlo - čovjek je stvoren na sliku Božju i iz toga proizlazi njegovo dostojanstvo, njegova prava i dužnosti. Crkva je davno prepoznala značaj poznavanja vlastita podrijetla i činjenicu da čovjek može ne poznavati svoj identitet ili da u slobodi može Boga zamijeniti idolom. Povijest je pak pokazala da i vodeće društveno-političke ideje mogu biti idoli (pred-rasude), odnosno ideologije. Protiv ideologija se bori znanjem ili, kako se kaže, znanošću za koju pak treba paziti da ne preraste u idol scijentizma. Obrazovanje je stoga ključan proces kojem je cilj oblikovanje identiteta te je stoga ono temeljni interes svakoga društva i politike. No, ima li politika unaprijed pravo na odgojno-obrazovni proces i kulturu? Naime, »bez politike nema države, a bez odgoja nema kontinuiteta u razvoju kulture ${ }^{14}{ }^{14}$ Dakle, s jedne strane održavanje moći i opstanka, a s druge ostvarenje vrijednosti. Čovjek je dio obaju »krugova « koji se ne mogu izjednačiti, ali se isto tako ne mogu u potpunosti odijeliti. Obrazovanje je iznimno složen, značajan i moćan proces u kojem se ti krugovi spajaju. Naime, kako piše Ivan Pavao II.:

»'Svi ljudi teže znanju', a predmet te težnje je istina. Sam svakodnevni život pokazuje kolika težnja navodi svakoga od nas da mimo onoga što samo po čuvenju opažamo možemo spoznati kako stvari zaista stoje. U vidljivom svemiru jedino čovjek ima ne samo sposobnost znanja, nego on također zna da zna, te s toga razloga upravlja duh prema pravoj istini stvari koje se pred njim pojavljuju. Nitko ne može ostati ravnodušnim pred istinom svoga znanja. Ako čovjek otkrije da je nešto lažno, on to samim time odbacuje; ako pak može otkriti istinu, osjeća se zadovoljenim. Ovu pouku priznaje sv. Augustin dok piše: 'Vidio sam mnogo ljudi koji hoće prevariti drugoga, ali nikoga koji bi htio biti prevaren'. «15

Koliko je istina važna za život svakog pojedinca, za njegovo ostvarenje sreće, a time i društva zajedno sa znanošću i brojnim drugim vrstama čovjekova djelovanja, enciklika ističe u nekoliko sljedećih redaka:

»S pravom se kaže da je osoba dosegla zrelu dob samo onda kada, prema svojim snagama, može razlikovati istinu od laži stvarajući tako vlastiti sud o pravoj istini stvari. U tome se sastoji razlog tolikih istraživanja, osobito u području znanosti koje su zadnjih stoljeća postigle tolike rezultate da su išle na ruku stvarnom napretku cijeloga čovječanstva. No, ne manju važnost od teorijskog

\footnotetext{
${ }^{13}$ Usp. Lavrnja, Pedagogija izmedu ideologije..., 86-87.

${ }^{14}$ Slavica JUKA, Ivica MUSIĆ, Mate BUNTIĆ, Prema filozofiji odgoja, Mostar, Filozofski fakultet Sveučilišta u Mostaru, 2007, 192.

${ }^{15}$ FR 25.
} 
ima praktično istraživanje: kažemo da je istraživanje istine upravljeno prema ispunjenju dobra. Osoba pak, ako se ponaša etički i ako djeluje prema slobodnoj i ispravnoj volji, stupa na put blaženstva i smjera prema savršenstvu. « ${ }^{16}$

Tako postaje razvidno koliko je važno biti obrazovan, čovjek znanja, baviti se znanošću, ne samo radi društvenog napretka, radi zanata i alata, već radi činjenice da čovjeka traganje za istinom vodi do Istine, uvodi u širi kontekst, $\mathrm{u}$ kontekst smisla i vrijednosti. ${ }^{17}$ Naime, kao što nas pravo znanje upoznaje $\mathrm{s}$ veličinom našega neznanja, tako nas i prava znanost upoznaje s granicama znanosti ili, kako je to uočio francuski matematičar i fizičar Henri Poincaré: »Znanost ne može biti dovoljna zato što vidi samo jedan dio čovjeka, ili, ako više volite, ona vidi sve, ali vidi sve s iste strane [...]. ${ }^{18}$ Istinsko znanje čovjeka vodi do zaključka da su vjera i razum »dva krila kojima se ljudski duh uzdiže k promatranju istine « ${ }^{19}$ Naime, istinskom znanošću čovjek dolazi do pitanja o istinskim vrijednostima. Zaista, ima li veće nevolje za čovjeka od nepoznavanja istine? I zaista, može li se naći većega čina ljubavi od: poučiti bližnjega, baš kao što Krist poučio svoje učenike, povesti ga na put traženja istine?

Crkva je, stoga, kao dio društveno-političke stvarnosti, tijekom stoljeća osjećala obvezu da se zalaže na polju obrazovanja. Naime, njezina misija evangelizacije podrazumijeva napor vraćanja dostojanstva najsiromašnijima, ${ }^{20}$ a siromaštvo nadilazi kategorije materijalnoga te proizlazi da je najsiromašniji čovjek koji nema znanja o vlastitoj vrijednosti. Stoga su se tijekom stoljeća brojni muškarci i žene posvećena života odlučivali za odgojno-obrazovno poslanje, odazvali su se zovu Providnosti, požrtvovno uložili sile u stjecanje znanja i hrabro se uključili u socio-političku stvarnost svoga vremena, ucijepili su živote u kreiranje i realizaciju odgojno-obrazovnih procesa da bi čovjeka doveli na put istine (primjeri su brojni: sv. Dominik, bl. Augustin Kažotić, don Ivan Bosco itd.). Naime, »ti pioniri obrazovanja duboko su shvatili ovo djelo milosrđa [neuka poučiti i dvoumna savjetovati] i učinili od njega način života koji je kadar preobraziti samo društvo «, ${ }^{21}$ istaknuo je papa Franjo. Na taj doista poseban oblik evangelizacije Crkva je danas, u vremenu tolikih previranja i nasrtaja na čovjekovo dostojanstvo, pozvana možda više nego ikada prije.

\footnotetext{
${ }^{16}$ FR 25.

${ }^{17}$ Detaljnije o suvremenim tendencijama (i njihovim posljedicama) razumijevanja znanosti i znanja kao robe vidi: Krešimir PERAČKOVIĆ, Društvena uloga znanstvenika danas. Znanstvenik kao homo economicus i homo sociologicus versus homo academicus universalis, Filozofska istraživanja, 36 (2016) 3, 581-593, 588-590.

${ }^{18}$ Henri POINCARÉ, Znanost $i$ hipoteza, Zagreb, Globus, 1989, 195.

${ }^{19}$ FR 5.

${ }^{20}$ Usp. Papa Franjo, Savjetovati i poučavati..., 26.

${ }^{21}$ Isto.
} 


\section{Obrazovanje u društveno-političkom kontekstu}

Povijesno gledano, tijekom prošlog stoljeća, osobito nakon drugog svjetskog rata, u društvu je došlo do brojnih promjena u području obrazovanja i odgoja. U obrazovanje se počelo ulagati sve više sredstava, obrazovne su se ustanove počele omasovljavati, a obrazovno-odgojni sustavi mijenjati. Stoga se u redcima Strategije obrazovanja, znanosti i tehnologije Republike Hrvatske iz 2014. tvrdi:

»Hrvatska prepoznaje obrazovanje i znanost kao svoje razvojne prioritete koji joj jedini mogu donijeti dugoročnu društvenu stabilnost, ekonomski napredak i osiguranje kulturnog identiteta. ${ }^{22}$

No, već su se šezdesetih godina pojavile dvije krize koje pokazuju koliko je prijeko potrebno promisliti shvaćamo li obrazovanje na ispravan način. Naime, prvo je uočena kriza obrazovanja. Ona je proizišla iz razočaranja u obrazovanje zbog njegovih razvojnih učinaka, odnosno zastarijevanja znanja uzrokovana ubrzanim tehnološkim i društvenim promjenama. To je rezultiralo preispitivanjem sustava, odnosno reformama kojima je bio cilj poboljšati učinkovitost i djelotvornost obrazovnih sustava. Hrvatsko je društvo s jednom takvom reformom jako dobro upoznato. No uz tu prvu krizu pojavila se i druga, kriza odgoja, koja se očitovala u nemoći škole da osigura pounutarnjenje stanovitoga svjetonazora iz čega izlaze poželjni stavovi i navike - odgojna učinkovitost škole slabija je od obrazovne. ${ }^{23} \mathrm{U}$ tom smislu treba uočiti sljedeće: uzroci odgojne krize složeniji su i manje transparentni, a posljedice odgojne krize na održiv razvoj teže su nego posljedice krize obrazovanja. Čini se ipak da se u suvremenom svijetu prije uočava obrazovna nego odgojna kriza i da se na obrazovnu krizu pokušava odgovoriti dok se oko odgojne krize na brojnim razinama vode rasprave. Glede toga treba uočiti, kao prvo, da postoje prijepori oko toga kako odrediti odgoj, odnosno u pozadini odgojno-obrazovnih problema našega društva zapravo leži pokušaj vrijednosne neutralizacije odgojno-obrazovnog procesa. Filozofijski, psihološki i sociološki gledano takvi pokušaji moraju završiti pogubno i za samoga čovjeka i za društvo. Naime,

»za održiv društveni razvoj, tj. za samo preživljavanje čovječanstva, svjetonazorske (vrijednosne) promjene postaju kritičnima jer o vrijednostima ovisi izbor ciljeva kojima ljudi teže, dok se obrazovanjem osposobljavaju za njihovo postizanje. Odgojna reforma treba pomoći preusmjeravanju razvoja dok obrazovna reforma treba poboljšati osposobljenost ljudi za ostvarenje ciljeva razvoja. $\ll^{24}$

\footnotetext{
${ }^{22}$ Strategija obrazovanja, znanosti i tehnologije, Narodne novine 124/2014, http://narodnenovine.nn.hr/clanci/sluzbeni/2014_10_124_2364.html (30.11.2018).

${ }^{23}$ Usp. Nikola PASTUOVIĆ, Edukologija. Integrativna znanost o sustavu cjeloživotnog obrazovanja i odgoja, Zagreb, Znamen, 1999, 17.

${ }^{24}$ Isto.
} 
No, treba naznačiti da odgoj i obrazovanje u svojoj srži nisu odvojivi procesi. Informacija je uvijek i oblik formacije - »vrijednosti su sastavni dio svih teorija obrazovanja ${ }^{25}$ Kao drugo, treba uočiti da se kultura određuje nasuprot prirodi, ali da vrijednosti od kojih je kultura sazdana ne mogu biti suprotne prirodi. Čovjek je biće koje mora poznavati i živjeti u skladu s prirodom i svojom naravi. Posljedice pokušaja transformacija istinskih vrijednosti za čovjeka završavaju ekološkim katastrofama, klimatskim promjenama, društvenim devijacijama i razaranjem temeljnih jedinica svakoga društva - obitelji.

\section{3. Što je zapravo obrazovanje?}

Obrazovanje je složen proces koji se kroz povijest razumijevao na različite načine. Sam termin potječe od lat. educere (educirati), a znači: izvoditi, trenirati, njegovati. Za pojam obrazovanje se u starijim hrvatskim izvorima koriste pojmovi: izobrazba (izobražavanje), koje zapravo shvaćamo kao poseban oblik obrazovanja uže transferne vrijednosti, i naobrazba (naobražavanje), koje shvaćamo kao rezultat najčešće formalnog obrazovanja. ${ }^{26}$ Pogledamo li u strane jezike vidimo da se ti pojmovi razlikuju.

»Obrazovanju (i odgoju) u engleskom jeziku odgovara riječ education, a izobrazbi training [...] U njemačkom jeziku za obrazovanje se rabi izraz die Bildung, a za izobrazbu die Ausbildung. U francuskom jeziku obrazovanje (i odgoj) je education, a izobrazba formation. ${ }^{27}$

Prema definiciji obrazovanje je organiziran proces učenja koji se izvodi pod vodstvom kvalificiranog odgojitelja i čini ga sustavno stjecanje spoznajnih (kognitivnih) i psihomotornih svojstava ličnosti, tj. stjecanje znanja o prirodi, društvu i ljudskom mišljenju, ovladavanje vještinama, stjecanje navika i oblikovanje kritičkog mišljenja. ${ }^{28}$

Obrazovanje se, kako vidimo, u svom fundamentu poklapa s onim što zovemo intelektualni odgoj, ali usko je vezano s drugim razinama odgoja. Obrazovanje je uži pojam od odgoja, ali širi od nastave i u tom smislu ga možemo podijeliti na neformalno i formalno obrazovanje, odnosno na predškolsko, osnovnoškolsko, srednjoškolsko, visokoškolsko itd. Upravo u obrazovanju i nastavi, kao najorganiziranijem obliku odgoja i obrazovanja, odgoj dolazi do punog izražaja. ${ }^{29} \mathrm{U}$ suvremenom se društvu izniman naglasak stavio na obrazovanje pa je danas »permanentno obrazovanje« opće poznat termin. Čovjek je

\footnotetext{
${ }^{25}$ Haralambos, Holborn, Sociologija..., 882.

${ }^{26}$ Usp. Pastuović, Edukologija..., 44.

${ }^{27}$ Isto.

${ }^{28}$ Usp. Franković i dr., Enciklopedijski rječnik pedagogije..., 575-576; Pastuović, Edukologija..., 44-45.

${ }^{29}$ Usp. Franković i dr., Enciklopedijski rječnik pedagogije..., 575-578.
} 
danas trajno u procesu obrazovanja. Obrazovanje je trajna sastavnica življenja. No, ono što se smatra trajnim u odgojno-obrazovnom procesu jest odgoj, tj. vrijednosti i brojne poteškoće izrastaju iz zaboravljanja te činjenice - uostalom, svaka spoznaja, svaka informacija traži od čovjeka da se prema njoj vrijednosno odredi.

Je li obrazovanje vrijedno ili je li potrebno - nikada nije bilo upitno, ali što bi trebalo biti sadržaj obrazovanja, to je veliki kamen spoticanja. ${ }^{30}$ Naime, sadržaj se može podijeliti na općeobrazovni i stručni, a riječ je o obrazovnim dobrima koja čine one sastavnice kulture koje, prenošenjem na nove generacije, služe njenom obrazovanju. Kriteriji po kojima nešto postaje sadržaj obrazovanja, odnosno obrazovno dobro, iznimno su važni. Razlikujemo uglavnom dva temeljna kriterija. Prvi kriterij nalaže da obrazovna dobra moraju biti primjerena psihofizičkim karakteristikama odgajanika. Drugi kriterij kaže da mora biti riječ o obrazovnoj vrednoti. Vrednote su pak društveno, kulturološki i povijesno uvjetovane. Tako sadržaj obrazovanja oblikuje tzv. obrazovni ideal, odnosno cilj prema kojem se usmjerava obrazovni proces.

Cilj obrazovanja je oblikovanje sposobnosti, odnosno stjecanje vještina, ali i stavova, interesa i kritičkog pogleda na svijet, što pojedincu omogućava ucjepljenje u društvo i njegovu izgradnju. U tom smislu, obrazovanje je i rezultat jer je obrazovanje odgajanikovo vlasništvo. S obzirom na to da je čovjek pak društveno biće, biće odnosa, dio obitelji, zajednice, društva, naroda i danas globalnoga sela, to odgajanikovo vlasništvo postaje jednako važno i za odgajanika i za društvo. Dakle, onim što je istrenirao, onim što je uvježbao, navikom koju je stekao, stečenom naobrazbom čovjek obogaćuje i izgrađuje sebe, ali i društvo, odnosno: »Što god nam se podmeće kao predmet naše spoznaje, to samim time postaje i dijelom našeg života. «11

Ono što nam ovaj mali uvid u određenje obrazovanja otkriva jest da je obrazovanje neodvojivo od treniranja, a treniranje (vježbanje) jest proces. Obrazovanje je u tom smislu proces izvježbavanja, odnosno proces gradnje i izgradnje, proces oblikovanja osobe, osobito njezinih kognitivnih sposobnosti. No, s obzirom na to da je općenito moguće i poželjno afektivnu, odnosno »čuvstvenu sastavnicu neke vrednote, stava ili navike utemeljiti na odgovarajućoj kognitivnoj osnovi ${ }^{32}$ postaje jasno da je obrazovanje nerazdruživo vezano s odgojem, odnosno da se obrazovanjem ujedno odgaja (o tome su govorili npr. Sokrat, Augustin, Toma Akvinski). U najširem smislu, »obrazovanje je jednostavno aspekt socijalizacije: uključuje stjecanje znanja i učenje vještina. Namjerno ili nenamjerno obrazovanje često utječe i na stvaranje uvjerenja i moralnih vrijednosti. (33 $^{33}$ Obrazovanje, dakle, nije i ne može biti, ono što suvremeno druš-

\footnotetext{
${ }^{30}$ Primjer takvih nesuglasica nalazimo u kontekstu kurikularne reforme u Republici Hrvatskoj.

${ }^{31} F R, 1$.

${ }^{32}$ Pastuović, Edukologija..., 48.

${ }^{33}$ Haralambos, Holborn, Sociologija..., 774.
} 
tvo često želi, vrijednosno neobojen, neki neutralan proces - informacija je ujedno formacija. Obrazovanje, u tom smislu, možemo upotrijebiti ili zloupotrijebiti, može postati proces formacije ili deformacije.

Stoga je iznimno važno tko kreira obrazovanje i tko i kako obrazuje. Papa Franjo je to rekao ovako:

»Postoji još jedno posljednje očekivanje koje želim podijeliti s vama: doprinos obrazovanja da sijemo nadu. Čovjek ne može živjeti bez nade, a obrazovanje stvara nadu. $U$ stvari, obrazovanje je rođenje, to je rast, rast u dinamičnosti davanja života. I život koji je rođen najbogatiji je izvor nade; Život dugo traži ljepotu, dobrotu, istinu i zajedništvo s drugima za zajednički rast. Uvjeren sam da je današnjoj mladosti iznad svega potrebna ovaj život koji gradi budućnost. Stoga je istinski učitelj poput oca i majke koji prenose život sposoban za budućnost.« ${ }^{34}$

Naoko paradoksalno činjenično stanje, da je u europskim zemljama s dobrim obrazovanjem najizrazitija kriza vjere, uopće nije paradoks već izvrstan primjer što se dogodi kada obrazovanje pokušamo svesti na informaciju i kad mu oduzmemo vrijednosnu dimenziju pa se njime više ne može formirati pojedinac spreman za susret s budućnošću u nadi.

\section{4. Čovjek - središte obrazovanja i evangelizacije}

Pitati što je obrazovanje, znači pitati što je čovjek, ${ }^{35}$ a čovjek je prvi i osnovni put Crkve, odnosno:

»Crkva ne može zanemariti čovjeka, jer čovjekova 'sudbina' - što znači izbor, poziv, rođenje i smrt, spasenje ili propast - sva je tijesno i nerazdvojivo sjedinjena s Kristom. I to se odnosi upravo na svakog pojedinog čovjeka na ovom planetu, na ovoj zemlji koju je Stvoritelj darovao prvom čovjeku kad je muškarcu i ženi rekao: 'Sebi je podložite.' Riječ je o svakom čovjeku u svoj neponovljivoj stvarnosti njegova bića i djelovanja, razuma i volje, savjesti i srca. Čovjek po svojoj pojedinačnoj stvarnosti (jer je 'osoba'), ima vlastitu povijest duše. Čovjek u skladu s unutrašnjim otvaranjem svoga duha zajedno $s$ tolikim i tako različitim potrebama svoga tijela, svog vremenitog postojanja, ispisuje tu svoju osobnu povijest preko brojnih veza, susreta, prilika, društvenih ustrojstava što ga povezuju s drugim ljudima. Sve to on čini od prvog časa svog zemaljskog postojanja, od začeća i rođenja. Čovjek u svoj istini svoga postojanja, svog osobnog, a također zajedničkog i društvenog bića - u krugu svoje obitelji, u krugu društva i tako različitih okolnosti, u okviru svoga naroda ili države (možda još uvijek samo u okviru klana ili plemena), u sklopu svega čovječanstva - taj je čovjek prva staza kojom Crkva mora proći ispunjavajući svoje poslanje. Taj je

\footnotetext{
${ }^{34}$ Papa Franjo, Discorso del santo padre...

${ }^{35}$ Usp. Anđelka PEKO, Obrazovanje, u: Antun MIJATOVIĆ i dr. (ur.), Osnove suvremene pedagogije, Zagreb, Hrvatski pedagoško-književni zbor, 1999, 203-222, 205.
} 
čovjek prvi i osnovni put Crkve, put što ga je sam Krist zacrtao, put što nepromjenljivo prolazi kroz otajstvo Utjelovljenja i Otkupljenja. « ${ }^{36}$

Naime, Crkva je po naravi misijska, tj. poslana je od Krista, preko apostola svim narodima, svakom čovjeku, naviještati i svjedočiti evanđelje i ona tu svoju službu mora ispunjavati do nakraj zemlje (usp. Dj 1,8). S obzirom na to da ta zadaća izvire iz same naravi Crkve, to je nužna zadaća svakog pripadnika Božjega naroda. Misijsko značenje te zadaće možemo nazvati i zadaćom evangeliziranja na koju svi moraju odgovoriti i to svaki prema svome položaju. ${ }^{37}$ Svaki prema svome položaju i prema svojim sposobnostima. Crkva i danas promišlja i traži nova rješenja za prenošenje vjere u konkretne živote, tj. socijalnu stvarnost. ${ }^{38}$

Crkva je u tom smislu suočena s dinamičnom i složenom stvarnošću evangelizacije koja uvijek pretpostavlja dvostrukost, odnosno, Crkva mora prepoznati potrebe vremena, tj. potrebe čovjeka na svim razinama društveno-političke stvarnosti, te, isto tako, svoje članove mora pripremiti i osposobiti da odgovore na te potrebe. Drugim riječima, kao što evangeliziranje pretpostavlja da smo prvotno sami evangelizirani, tako odgovor na potrebe vremena i evangeliziranje u suvremenom svijetu znači upoznati kontekst vremena, imati znanje o vremenu i njegovim problemima, obrazovati se da bi se obrazovanjem moglo odgojiti za evanđelje. Naime, »u svijetu u kojem je sekularizacija postala selektivno sljepilo za nadnaravno, a ljudi izgubili Božje tragove, pozvani smo ponovno otkriti i proučavati temeljne istine vjere «. ${ }^{39}$ To podrazumijeva, kako je isticao Ivan Pavao II., među ostalim, obnavljanje ljubavi prema kulturalnom zauzimanju i jače posvećivanje studiju radi cjelovite formacije. ${ }^{40}$ Kvaliteta, odgovornost i zalaganje na svim poljima, prema položaju, mogućnostima i sposobnostima, ali na svim područjima, a osobito na visokospecijaliziranima, jer znanost bez vrijednosnih dimenzija postaje opasna. To su nova raskrižja na koja smo pozvani, raskrižja na kojima čovjek traga za smislom. Hoćemo li stupiti na njih? - možda i nije pravo pitanje. S čime ćemo stupiti na ta raskrižja? - možda je bolje pitanje.

Davno je Ivan Pavao II. istaknuo da je sadržaj evangelizacije uvijek isti, a razlike u djelovanju (neke misijske) Crkve ne proistječu iz uzroka koji bi bili

${ }^{36}$ IVAN PAVAO II., Redemptor hominis - Otkupitelj čovjeka (4.III.1979), br. 14, Zagreb, Kršćanska sadašnjost, 1980, 35, (dalje RH).

${ }^{37}$ Usp. Rudolf BRAJČIĆ, Mato ZOVKIĆ, Dogmatska konstitucija o Crkvi - Lumen gentium, I, Zagreb, Filozofsko-teološki institut Družbe Isusove, 1977, 309, 316. Detaljnije o određenju pojmova »evangelizacije« i »nove evangelizacije«, u: Nikola BIŽACA, Značenje evangelizacije i nove evangelizacije u govoru crkvenog učiteljstva, Crkva u svijetu, 34 (1999) 4, 419-436.

${ }^{38}$ Usp. SINODO DEI VESCOVI, La nuova evangelizzazione per la trasmissione della fede cristiana. Instrumentum laboris, Città del Vaticano, 2012, br. 130.

${ }^{39}$ KONGREGACIJA ZA USTANOVE POSVEĆENA ŽIVOTA I DRUŽBE APOSTOLSKOG ŽIVOTA, Istražujte. Posvećenim muškarcima $i$ ženama u hodu za Božjim znakovima (8.IX.2014), br. 9, Zagreb, HKVRPP, 2015, 32-33.

${ }^{40}$ Usp. IVAN PAVAO II., Vita consecrata. Apostolska pobudnica o posvećenom životu i njegovu poslanju u Crkvi i svijetu (25.III.1996), br. 98, Zagreb, Kršćanska sadašnjost, 1996, 164. 
vlastiti samoj misiji, već iz okolnosti u kojima se ona provodi. Stoga, promatramo li današnji svijet pod vidom evangelizacije, možemo razlikovati tri situacije na koje Crkva mora prikladno odgovoriti, na zahtjeve triju različitih konteksta suvremenog društva. Prvi kontekst su ljudske skupine, tj. socio-kulturni kontekst u kojem Krist i evanđelje nisu poznati ili gdje još nema zrelih kršćanskih zajednica, tzv. misija ad gentes. Drugi kontekst su kršćanske zajednice koje imaju primjerene i čvrste crkvene strukture i gorljive su u vjeri i životu te se $u$ njima odvija djelo i pastoralna skrb Crkve. Treći kontekst su većinom zemlje staroga kršćanstva, a katkad i mlađe crkve, svojevrsno srednje stanje gdje su cijele skupine krštenih izgubile živi osjećaj vjere ili se više uopće ne priznaju članovima Crkve, žive život koji je daleko od Krista i evanđelja i u tom je slučaju nužna nova ili ponovna evangelizacija. ${ }^{41}$

Uz to, naše je vrijeme dinamično i ujedno očaravajuće. S jedne strane čovjek teži materijalnom blagostanju i utapa se u potrošačkom materijalizmu, a s druge tjeskobno traži smisao. Čovjek jednostavno ne može izbrisati svoju duhovnu dimenziju i u tom je smislu pojava tzv. religioznog povratka poziv Crkvi da čovjeka »povede« ususret Bogu. Crkva to mora učiniti poput sv. Pavla na raznim areopazima suvremenog svijeta. Primjerice, u zauzimanju za mir, za razvoj, prava čovjeka, zaštitu prirode, za kulturu, znanstvena istraživanja međunarodne odnose, a najviše za prvi areopag današnjega vremena, za svijet komunikacije. ${ }^{42}$ Za svaki kontekst, za svaki areopag, Crkva mora naći, prikladan i razumljiv jezik, odnosno:

»Neprijeporna važnost koju ima sadržaj evangelizacije nipošto nas ne smije omesti da shvatimo kolika je važnost njenih putova i sredstava. Uvijek je suvremeno pitanje kako evangelizirati jer se načini evangelizacije mijenjaju prema različitim okolnostima vremena, mjesta, kulture i tako su, na neki način, izazov našoj sposobnosti otkrivanja i prilagođavanja. Posebno moramo nastojati mi, pastiri u Crkvi, da odvažno i mudro, potpuno vjerni sadržaju, pronalazimo najprilagođenije i najdjelotvornije načine za prenošenje evanđeoske poruke ljudima našeg vremena. U svom razmišljanju spominjemo samo nekoliko putova koji su s ovog ili onog razloga od temeljne važnosti.« ${ }^{43}$

Enciklika redom nabraja: svjedočanstvo života, živu propovijed, službu Riječi, katehezu, upotrebu mass media, a na taj niz nova promišljanja neupitno dodaju obrazovanje. ${ }^{44}$

Štoviše, na početku svoga pontifikata papa Franjo je ponovio poziv na evangelizaciju i pozvao na razvijanje kulture dijaloga, a prigodom Godine posvećena života pozivao je Crkvu da bude »Crkva koja izlazi ${ }^{45}$ da bude ona koja odgaja

\footnotetext{
${ }^{41}$ Usp. RH, 33.

${ }^{42}$ Usp. RH, 57-58.

${ }^{43} \mathrm{EN}, 40$.

${ }^{44}$ Usp. Sinodo dei Vescovi, La nuova evangelizzazione..., 2012, br. 147-152.

${ }^{45}$ Usp. Kongregacija za ustanove posvećena života i družbe apostolskog života, Istražujte..., br. 1, 7.
} 
za evanđelje i njegove zahtjeve, da ispita vlastite formacijske paradigme da bi mogla stati na raskrižja svijeta. Odgajati i obrazovati za evanđelje može samo onaj tko je evangeliziran, obrazovan i odgojen. Papa Franjo je pitao još i ovako:

»Gdje će biti posvećene osobe? Hoće li slobodni od svih sponâ zbog evanđeoskog načina života na kojeg se zavjetuju znati živjeti na pragu? Hoće li znati stati - poput straže - na margine gdje pogled postaje jasniji, a misao prodornija i poniznija? Hoće li sav posvećeni život znati prihvatiti izazov pitanjâ smisla koja dolaze s raskrižjâ svijeta?

Iskustvo siromašnih, dijalog među religijama i među kulturama, komplementarnost muškarca i žene, ekologija u bolesnom svijetu, nezadrživa eugenika, globalizirana ekonomija, planetarna komunikacija, simbolički jezik - sve su to novi hermeneutički obzori koje se ne smije samo nabrojiti, već ih treba nastaniti i učiniti da procvjetaju životom pod vodstvom Duha Svetoga koji u svemu uzdiše (usp. Rim 8, 22-27). To su epohalna gibanja koja ponovno pokreću pitanje sustavâ vrijednosti, jezikâ, prioritetâ, antropologijâ. Milijuni osoba su na putu prema svjetovima i kulturama, destabilizirajući stoljetni identitet i pospješujući miješanje kulturâ i religijâ.

Hoće li posvećeni život znati postati prijateljski sugovornik 'onoga traženja Boga koje oduvijek pokreće čovjekov srce'? Hoće li - poput Pavla - znati poći na atenski trg i zboriti poganima o nepoznatom Bogu (usp. Dj 17, 22-34)? Hoće li znati jačati žar misli kako bi se oživjelo vrijednost drugotnosti i etiku razlikâ u miroljubivom suživotu?»46

\section{Oblikovati čovjekovo lice}

Obrazovanje i evangelizacija su procesi oblikovanja čovjekova »obraza«, »lica«, odnosno »lika«. Čovjek s obrazom je moralan čovjek, čovjek od riječi. Ima li što gore od neimanja obraza? Ima li što gore od gubljenja obraza? Obrazovan bi čovjek trebao biti naobražen, čovjek s obrazom. Naime, znanje bez morala je krnje, često i opasno jer vodi u uobražaj, a uobražen čovjek ne poznaje ni svoje granice ni granice znanja. Davno je Sokrat čovjeku »ponosnom na svoje obrazovanje živo predočio da je uvid u vlastito neznanje početak svega znanja«. ${ }^{47}$ Istinski obrazovan čovjek je ponizan, čovjek koji poznaje granice znanosti i vlastita znanja. Obrazovanje tako uistinu jest poseban oblik evangelizacije jer je vodi ususret granicama, obzorima iza kojih stoji Stvoritelj, znanje vodi onkraj zanata i alata ususret vrijednostima. Evangelizacija i obrazovanje su odgojni procesi koji zahtijevaju cjelovitost, čovjekov integralni rast. Obrazovanje je proces oblikovanja osobe, njezina obraza, a evangelizacija je proces preobrazbe čovjeka:

\footnotetext{
${ }^{46}$ Isto, br. 15, 47.

${ }^{47}$ Milan POLIĆ, K filozofiji odgoja, Zagreb, Znamen i Institut za pedagogijska istraživanja, 1993, 35 .
} 
»Što se Crkve tiče, navijestiti evanđelje znači unijeti Radosnu vijest u svaku ljudsku sredinu i u tom srazu samo čovječanstvo iznutra preobraziti, učiniti ga novim: 'Evo, sve činim novo!' No, nema novog čovječanstva ako najprije nema novih ljudi, krsne novosti i života prema evanđelju. Dakle, svrha evangelizacije zapravo je ta unutrašnja promjena $i$, ako bi se to smjelo izraziti jednom riječi, Crkva naviješta evanđelje dok samom božanskom snagom Poruke koja se naviješta ide za tim da istovremeno obrati osobnu i kolektivnu svijest ljudi, njihovo djelovanje, život i njihove stvarne životne sredine.« ${ }^{48}$

Dakle, unutarnje promjene nema bez spoznaje, a spoznaja koja se nema potrebu utjeloviti i nije prava spoznaja. Spoznaja, srce obrazovanja, tako postaje temelj oblikovanja obraza i preobražaja. Briga za čovjeka i njegov obraz, očuvanje čovjekova dostojanstva, temeljna je zadaća Crkve.

\section{Zaključak}

Svjesna svoga poslanja u današnjem vremenu edukacije i komunikacije Crkva prepoznaje obrazovanje kao doista poseban i moćan proces evangelizacije. Suvremene su tendencije da se obrazovanje prikaže isključivo kao roba, kao informacija, a ponekad još više: želi ga se prikazati nespojivim s evangelizacijom. No upravo suprotno, istinsko obrazovanje kao traganje za istinom nije samo proizvod, neka roba, nije puka informacija već sjeme novoga života koje je uvijek nova dinamična formacija. Stoga, kako papa Franjo uočava, obrazovanje je, kao briga za istinu, konstitutivna stvarnost poslanja Crkve. Crkva je odgovorna za istinu - svakog čovjeka upoznati s istinom njegova božanskog podrijetla koje je izvor njegova dostojanstva, prava i odgovornosti. Crkva stoljećima čuva informaciju o Istini koja ima moć preobrazbe.

U tom je smislu ovo najprikladnije završiti i danas aktualnim riječima pape Lava XIII. koje preuzima papa Ivan Pavao II. u enciklici Centesimus annus prigodom 100. obljetnice enciklike Rerum novarum. Nakon što je formulirao načela i usmjerenja za rješenje radničkoga pitanja, Lav XIII. napisao je vrlo važne i snažne riječi koje, u kontekstu ovoga promišljanja, mogu poslužiti kao poticaj i smjernica: »Neka svatko radi ono što na nj spada i neka ne oklijeva, jer ako se kasni, moglo bi liječenje jedne već tako teške bolesti biti još teže«, dodavši također: »Što se tiče Crkve, ona neće nikada ni na kakav način propustiti što je njezin posao. ${ }^{49}$

\footnotetext{
${ }^{48} \mathrm{EN}, 18$.

${ }^{49}$ Navedeno prema: IVAN PAVAO II., Centesimus annus - Stota godina. Enciklika (1.V.1991), br. 58, Zagreb, Kršćanska sadašnjost, 2001, 103.
} 


\section{Marina Novina* \\ Education and Evangelization}

Summary

With the insight into the process of education, in the relationship between education and culture and in the place of education in the socio-political context, this research led to the conclusion that education and evangelization are two powerful and inseparable processes of shaping human identity, because every information is at the same time formation. Therefore, it is essential for the Church to take part in educational processes and their creation. Caring for the truth and acquainting man with the truth about his origin, dignity, rights, and responsibilities, the Church is responsible for information that has the power of transformation, i.e. the formation of man's identity and faculties. Caring for the truth implies care of information, which is the core of the process of evangelization and caring for human being, his identity and his face, and the way of the Church that Church should never abandon. Education is the fundamental charisma of the Church and a powerful form of evangelization.

Key words: Education, Cognition, Truth, Information, Evangelization, Culture, Human Being.

(na engl. prev. Marina Novina)

\footnotetext{
* Marina Novina, PhD, Assistant, University of Zagreb, Faculty of Philosophy and Religious Studies; Address: Jordanovac 110, HR-10000 Zagreb, Croatia; E-mail: marina.novina@ffrz.hr.
} 